\title{
Persistent Gaps of Knowledge for Naming and Distinguishing Multiple Species of Crown-of-Thorns-Seastar in the Acanthaster planci Species Complex
}

\author{
Gerhard Haszprunar ${ }^{1,2, *}$, Catherine Vogler ${ }^{3}$ and Gert Wörheide ${ }^{3,4}$ \\ 1 Staatliche Naturwissenschaftliche Sammlungen Bayerns (SNSB)-Zoological State Collection, \\ Münchhausenstraße 21, D-81247 Munich, Germany \\ 2 Department Biology II and GeoBio-Center, Ludwig-Maximilians-Universität München, \\ D-80539 Munich, Germany \\ 3 Department of Earth and Environmental Sciences, Paleontology \& Geobiology, and GeoBio-Center, \\ Ludwig-Maximilians-Universität München, Richard-Wagner-Straße 10, D-80333 Munich, Germany; \\ catherine.vogler@gmail.com (C.V.); woerheide@lmu.de (G.W.) \\ 4 SNSB-Bavarian State Collections of Palaeontology and Geology, D-81827 Munich, Germany \\ * Correspondence: haszi@zsm.mwn.de; Tel.: +49-89-8107-104
}

Academic Editors: Morgan Pratchett and Sven Uthicke

Received: 19 September 2016; Accepted: 9 May 2017; Published: 12 May 2017

\begin{abstract}
Nearly a decade ago, DNA barcoding (partial mitochondrial COI gene sequences) showed that there are at least four species in the Indo-Pacific within what was previously conceived to be a single Crown-of-Thorns-Seastar (COTS) species, Acanthaster planci. Two of these species-A. planci Linnaeus, 1758, distributed in the North Indian Ocean, and A. mauritiensis de Loriol, 1885, distributed in the South Indian Ocean-have been already unequivocally named. In contrast, the Pacific COTS (proposed name: A. solaris (Schreber, 1795) and the COTS from the Red Sea (still to be named) require further taxonomic work. COI barcoding sequences and Barcode Identification Numbers (BINs) are available for all four COTS species in the global Barcode of Life Database (BOLD). We recommend depositing voucher specimens or tissue samples suitable for DNA analyses when studying any aspect of COTS, and use BINs to identify species, to ensure that no information is lost on species allocation until unequivocal Linnean names are available for the Pacific and Red Sea species as well. We also review the differences between COTS species with respect to morphology, ecology, and toxicity. Future studies should widen the current biogeographic coverage of the different COTS species by strategically sampling neglected areas, especially at the geographic distribution limits of each species, to enhance our understanding of the diversity of this reef coral predator.
\end{abstract}

Keywords: COTS; taxonomy; Linnean names; DNA-barcodes; Barcode Index Numbers; biogeography

\section{Introduction}

There is little doubt that the Crown-Of-Thorns-Seastar (COTS), usually referred to as Acanthaster planci (Linnaeus, 1758), with its corallivorous lifestyle and strong tendency to mass outbreaks, is one of the most serious threats to coral reefs throughout the Indo-Pacific marine biome, and numerous studies over the last decades have addressed all aspects concerning this point (reviewed in [1]). These circumstances have led to Acanthaster planci's being the most researched and cited of all echinoderm species.

For more than 250 years, researchers have noticed morphological differences among specimens of COTS from different geographical areas. Indeed, a number of taxa have been proposed, and these have 
subsequently been merged again or split further (for a review, see [2]). Currently, only one other species aside from Acanthaster planci is uniformly accepted as valid within the genus, Acanthaster brevispinus Fisher, 1917 [3]. This species does not feed on coral and thus does not threaten coral reefs. Yet during the last 30 years, various molecular datasets have suggested that Acanthaster planci might be more than a single species [4-8]. The most thorough molecular and phylogeographic study that included Acanthaster planci specimens across its entire Indo-Pacific distribution range (from the Red Sea to Mauritius and the Eastern Pacific) revealed no less than four deeply divergent clades [9]. The "barcoding fragment" of the mitochondrial COI gene showed high inter-clade divergence (8.8-10.6\%) compared to $<0.7 \%$ intra-clade divergence, strongly suggesting that Acanthaster planci represents a species complex with four different species instead of a single one [9]. These species (and we use the term "species" henceforth) show distinct geographical distribution patterns across the Indo-Pacific: one species might be restricted to the Red Sea, one occurs in the Northern Indian Ocean, another one mainly in the Southern Indian Ocean (with the exception of Northern Oman), and the fourth species shows a pan-Pacific distribution (Table 1; Figure 1, references [9-11]). Moreover, the Pacific species shows some internal phylogeographic structure [12-14], accordingly it cannot be excluded that additional (sub-)species be discovered here in the future using higher-resolution molecular markers, such as SNPs.

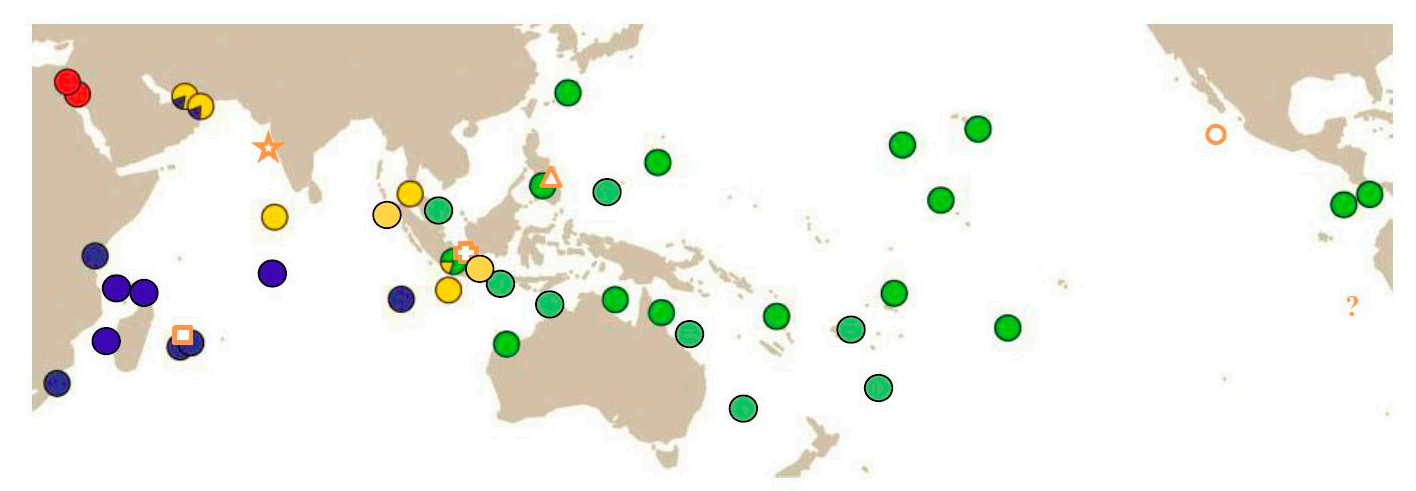

Figure 1. Geographic distribution of COI-barcoded species and of type localities of names (combined and modified from [2] and [9-11]: red-Red Sea (RS) species; blue-South Indian Ocean (SIO) species (A. mauritiensis); yellow-North Indian Ocean (NIO) species (A. planci); green-Pacific Ocean (PO) species (A. solaris). Location of type localities of nominal (sub-)species: asterisk-A. planci; cross-A. echinites; triangle-A. solaris, square-A. mauritiensis; circle-A. ellisii pseudoplanci; "?"-the type locality of $A$. ellisii was not specified: in South American waters of the East Pacific. 
Table 1. Summary of Linnean nomenclature, Biological Index Number (BIN) and distribution of currently recognized Organismic Taxonomic Units (OTUs) of the Acanthaster planci species complex based on Vogler et al. [9-11] and Haszprunar \& Spies [2]. See text for details.

\begin{tabular}{|c|c|c|c|c|}
\hline $\begin{array}{c}\text { OTU (Vogler et al., } \\
2008 \text { [9]) }\end{array}$ & NIO Species & SIO Species & Pacific Species & Red Sea Species \\
\hline Name [proposed] & A. planci (Linnaeus, 1758) & $\begin{array}{l}\text { A. mauritiensis de } \\
\text { Loriol, } 1885\end{array}$ & [A. solaris (Schreber, 1795)] & NN (not yet named) \\
\hline Type locality & $\begin{array}{c}\text { off Goa, } \\
\text { West Indian coast }\end{array}$ & off Mauritius & Magellan Street, Philippines & - \\
\hline BIN (BOLD) & AAA1633 & AAA1631 & AAA1630 & AAA1632 \\
\hline $\begin{array}{l}\text { Synonyms } \\
\text { [proposed] }\end{array}$ & $\begin{array}{c}\text { [A. echinites (Ellis \& } \\
\text { Solander in Watt, 1786)] }\end{array}$ & - & $\begin{array}{c}\text { A. ellisii (Gray, 1840) } \\
\text { A.e.pseudoplanci Caso, } 1962\end{array}$ & - \\
\hline Distribution & North Indian Ocean & $\begin{array}{c}\text { South Indian } \\
\text { Ocean (except West } \\
\text { Australian coast) }\end{array}$ & $\begin{array}{l}\text { Pacific Ocean and West } \\
\text { Australian coast }\end{array}$ & Red Sea \\
\hline $\begin{array}{l}\text { Outbreak ability } \\
\text { number of arms }\end{array}$ & $\begin{array}{c}\text { Yes } \\
\max .23\end{array}$ & $\begin{array}{c}\text { yes } \\
\text { max. } 23\end{array}$ & $\begin{array}{l}\text { Yes } \\
\max .23\end{array}$ & $\begin{array}{c}\text { yes } \\
\text { max. } 13-14\end{array}$ \\
\hline Specific color & "electric-blue" & light blue to rusty & $\begin{array}{l}\text { gray-green to gray-purple, } \\
\text { bulls-eye appearance }\end{array}$ & $\begin{array}{l}\text { gray-green to } \\
\text { gray-purple, bulls-eye } \\
\text { appearance }\end{array}$ \\
\hline $\begin{array}{l}\text { Harmfulness to } \\
\text { humans }\end{array}$ & harmful & harmful & very harmful & less harmful \\
\hline
\end{tabular}

\section{Nomenclatorical Status and Problems}

When established in 2008, Vogler et al. [9-11] did not correlate the four species with any Linnean taxon names. This could explain why their results have not been considered in most studies on COTS biology and ecology published since then, despite the potential implications of these findings for COTS research and conservation.

This unfortunate situation was only partially overcome by a recent thorough nomenclatorial study [2], which linked available names of two of the four species-(1) Acanthaster planci (Linnaeus, 1758) (with type locality Goa, West Indian coast) and Acanthaster mauritiensis (de Loriol, 1885) (with type locality Mauritius Island, [15]) with the Northern Indian Ocean (NIO) species and the Southern Indian Ocean (SIO) species, respectively. The Red Sea species still needs formal description, which is currently in progress by Gerhard Haszprunar and Gert Wörheide.

In contrast, the Pacific species, the most frequently studied one, is still somewhat equivocal in its nomenclature. The type localities of two of the previously described nominal species fall into the actual distribution area (Figure 1): (a) Acanthaster solaris (Schreber, 1795) has been described as being likely from the area around Cebu in the Philippines (see [2] for the specifics of the problems concerning the exact localization of the type locality). (b) Acanthaster echinites (Ellis \& Solander in Watt, 1786) has its type locality "from Batavia", i.e., off Jakarta, Indonesia. According to Vogler et al. [9], the latter region shows sympatry between the North Indian Ocean (A. planci) and the Pacific species. There is no type material of $A$. echinites left, and the original description can be applied to both species. Since Schreber [16] expressively distinguished his specimen from the description by Ellis \& Solander (in [17]), we prefer the interpretation made by the authors of [2] that A. echinites is a synonym of A. planci and that $A$. solaris is the valid name for the Pacific species. For formal clarification, the designation of a neotype from off Jakarta is necessary to make the species name Acanthaster solaris (Schreber, 1793) [16] unequivocally available for this species (currently in progress by Gerhard Haszprunar and Gert Wörheide).

Acanthaster ellisii (Gray, 1850) and Acanthaster ellisii pseudoplanci (Caso, 1962) have both been described as from East Pacific regions (Figure 1). However, all molecular analyses to date have united these populations within the Pacific species (same Barcoding Identification Number (BIN), see below), although the Pacific clade shows a significant substructure [12-14]. The Eastern Pacific COTS populations certainly deserve more in-depth future studies to clarify their taxonomic relationships. 


\section{Why Taxonomy of COTS Does Matter-Differences between A. planci Species}

The fact that the existence of these four species has largely been ignored by the COTS research community over the last decade may also be due to a certain reluctance to accept the identification of species based on molecular data rather than on more traditional methods, such as morphological characters or biological traits. However, the most recent publications on COTSs increasingly reflect the reception of the species complex and its implications (e.g., [18-23]).

Yet, although no thorough study was ever conducted to directly compare the biology of any of these four putative species, when digging through the COTS literature of the past 50 years, there are some indications pointing towards differences between them. The comparisons are limited by the fact that the overwhelming majority of COTS research was conducted on the Pacific species (Acanthaster solaris), nevertheless the few studies conducted in the Red Sea and the Indian Ocean indicated some differences. Here, we present a brief review of these differences (and in some cases lack of differences) for various aspects.

\subsection{Morphology}

There are indications of species-specific differences in the number of arms between the various species of the A. planci species complex. Reports and photos available through various websites reveal a maximum of 23 arms for the Pacific species, whereas the Red Sea species has a maximum of only 13-14 arms (e.g., [24]). However, since the number of arms increase with age and size, this character appears to be of minor importance. The same appears to be true for the length of arms which seem to be shorter in East Pacific populations (often called Acanthaster ellisii), although not statistically significant [25].

Differences between A. brevispinus and all COTS species are currently restricted to the shape of pedicellariae and spines [23], but thorough morphological comparisons by Scanning Electron Microscopy (SEM) or Micro-Tomography $(\mu \mathrm{CT})$ may uncover new differences between these taxa. A focus of future morphological comparisons using these techniques may especially be the East Pacific populations of the Pacific species, which were formally described as Acanthaster ellisii pleudoplanci (Caso, 1962) [26]. Finally, there are significant differences in spine length between the population of COTSs from Ambon Islands (Molluken Archipelago, Indonesia) and that from Papua Islands [27], which may reflect a difference between the true A. planci (Northern Indian Ocean species) and the Pacific species, A. solaris. We cannot rule out that further significant morphological differences between species will be detected in more comprehensive morphometric studies.

The most obvious aspects of morphological variation identified so far are the differences in color detected between the Pacific species and those of the Indian Ocean (A. planci and A. mauritiensis). COTSs in the Pacific Ocean are variable in color [27]: they are usually gray-green to gray-purple, often with reddish papulae that typically take on a "bulls-eye" appearance due to two rings of darker papulae (Figure 2a; [27]). Specimens of the Red Sea species are of a similar type of color (Figure 2b; [27]). However, specimens of the true A. planci tend to have a very different color, sometimes referred to as "electric blue" (Figure 2c,d; [27]; personal observations by all authors). This "electric blue" is also not found in A. mauritiensis. The latter species appears to range from a light blue to a rusty color (Figure 2e,f; Catherine Vogler and Gerhard Haszprunar pers. obs.). Whether the "electric blue" color exactly matches the genetic affiliation of the true A. planci, especially in the contact zone with other species, has yet to be fully confirmed. 

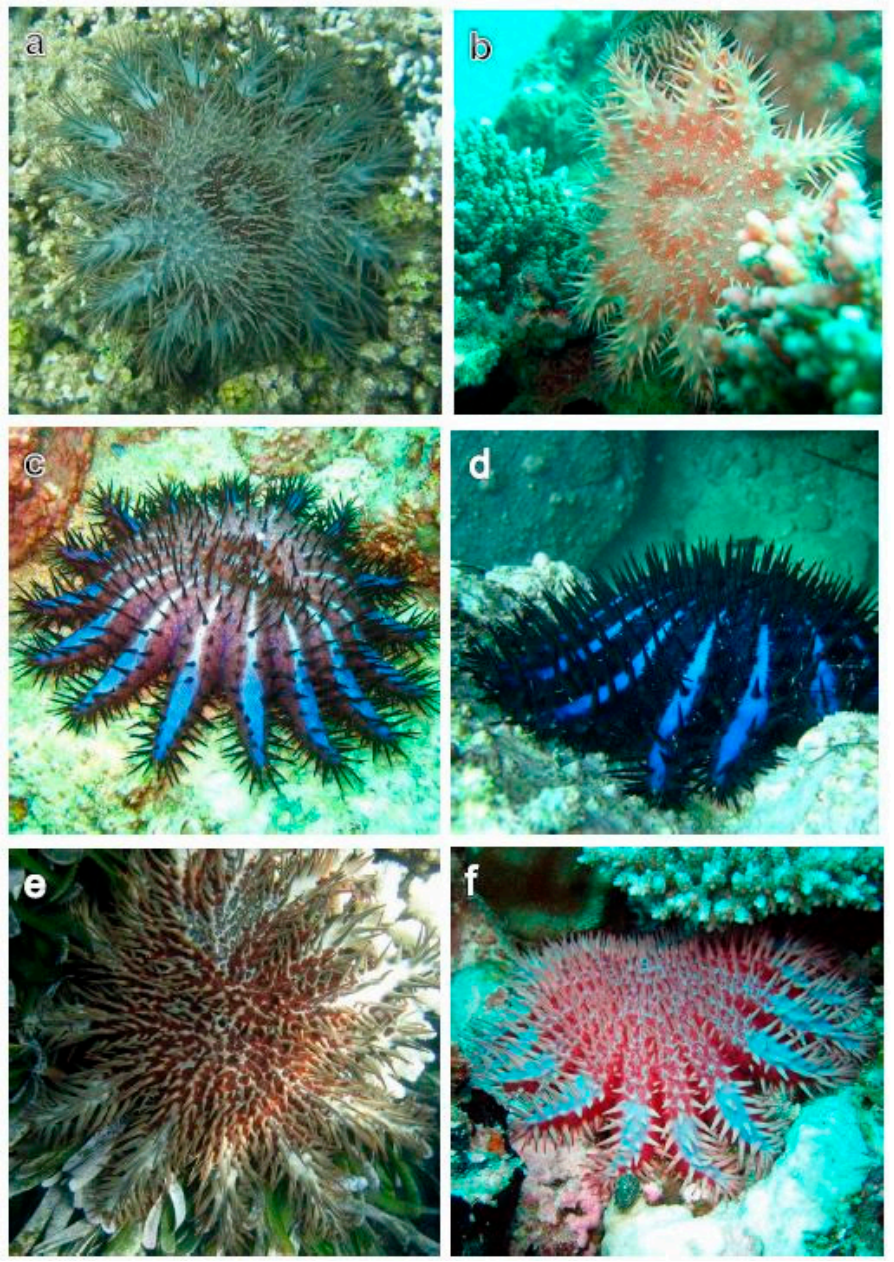

Figure 2. "Typical" color morphs found in the sister-species: (a) Pacific species, Fiji (tentatively Acanthaster solaris (Schreber, 1793)) (credit: Nina Yasuda), (b) yet unnamed Red Sea species (credit: Jessica Bouwmeester), (c) and (d) Northern Indian Ocean species, i.e., the true Acanthaster planci (Linnaeus, 1758), (c) UAE (credit: Maral Shuriqi); (d) Oman (credit: David Mothershaw), (e,f) Southern Indian Ocean species, i.e., Acanthaster mauritiensis de Loriol, 1885, (e) Kenya (credit: Kevin Ransom), and (f) Chagos Archipelago (credit: Anne Sheppard).

Summing up, it is not unlikely that distinct morphologies can be applied to distinguish the various species of COTS, but up to now an integrative approach to resolve COTS taxonomy is still missing.

\subsection{Toxicity}

The toxicity of Red Sea and Pacific COTSs also appears to be different. There is no evidence for a strong venom in Red Sea COTS, based on the reaction of divers from the Cambridge Coral Starfish Research Group to the penetration of spines: "although most members of the expedition were often pricked by their sharp spines, only one animal gave any real discomfort to both of the people who handled it" [28]. Pacific COTS, on the other hand, were found to inflict a range of different symptoms, from severe pain for several hours to persistent nausea and fever for several weeks or even permanent abscesses, apoptosis, hemolysis, and bone-destroying processes (reviewed in [27]). This depended on the number of spines penetrating, whether they broke off in the wounds, possible variability between individual sea-stars and different sensitivities of the victims [27]. Because it is improbable that all members of the Cambridge Coral Starfish Research Group were all particularly insensitive to COTS-inflicted wounds, Red Sea COTSs probably have significantly lower toxicity than the Pacific COTSs (no clear data are available on the other two species from the Indian Ocean). As toxicity is likely 
to evolve as a defense against predation, this could even be part of the reason why Red Sea COTSs are predominantely nocturnal (Gert Wörheide pers.obs.), as their defense system may be less efficient than that of Pacific COTSs. Since overexploitation of predators has been proposed as one possible cause of COTS outbreaks $[27,29]$, these differences in cryptic behavior and toxicity are far from trivial. Indeed, outbreaks are much more intensive in the Pacific Ocean compared to the Red Sea, and investigations of whether higher predator pressure, higher toxicity, or different behavior in the latter is the main cause of this difference may shed new light on this question.

\subsection{Outbreaks}

All species of COTS tend to produce outbreaks and mass aggregation, although this appears more frequently in the Pacific species [30]. The causes of outbreaks are still debated (see recent review [1]), and two main hypotheses have gained the highest support to date: (1) the "larval starvation hypothesis", which argues that increased nutrient levels favor the survival of COTS larvae [27,30-32], and (2) the "predator removal hypothesis", which suggests that the overexploitation of predators allows more larvae and juveniles to survive to maturity $[27,29]$. Outbreaks in the different COTS species could have different causes, and the different species could, for example, react differently to increased nutrient levels or the removal of predators. As such, obtaining a more thorough understanding of the biology of the Red Sea and the two Indian Ocean species and the causes of outbreaks in these species could also help understand more about the Pacific species as well, e.g., by giving new clues and opening new avenues of research. Therefore, comparative studies between the four species are needed to gain more insight into this major management issue of coral reefs.

\subsection{Conclusions}

To conclude, despite the limited amount of information available on COTSs from the Red Sea and the Indian Ocean, several differences suggest divergent biology and ecology of the four COTS species. Further research is definitely needed to establish whether these rather anecdotal observations can be substantiated to significantly increase our appreciation of the differences in the biology of the individual species in this species complex.

It is likely that there are differences in color patterns between the four species, and in-depth morphological (SEM, $\mu \mathrm{CT}$ ) and morphometric analyses may uncover further differences that may characterize each species. In particular, the larval and juvenile stages are in urgent need of more comparative data outside the Pacific species, Acanthaster solaris, since these probably play a critical role in the causes of outbreaks [27,29-32]. Finally, to understand differences between the sister-species and the degree to which they have diverged, interbreeding experiments are also important. Sympatric occurrence of different COTS species has been observed in two areas: the Gulf of Oman, where A. planci and A. mauritiensis co-occur and at the Indian/Pacific break (Indonesian waters), where individuals of $A$. planci and of the Pacific sister-species Acanthaster solaris co-occur [2,9-11]. Due to its maternal inheritance, the available data from mitochondrial DNA [9-12] prevent unequivocal inference of reproductive barriers. Data from biparentally inherited allozymes suggest there was little gene exchange between the Northern Indian (Acanthaster planci) and Pacific Ocean (Acanthaster solaris) species, but that there may have been introgression in the mixed population of Pulau Seribu [14]. However, the data are somewhat inconclusive due to small sample sizes, and the potential incomplete segregation of ancestral genotypes [5]. Further research with high-resolution nuclear molecular markers will thus be necessary to determine whether there are introgression events or even hybridization zones in the contact areas. Lucas et al. [33] crossed specimens from the Pacific species $A$. solaris with $A$. brevispinus, the short-spined sister-species of the COTS species complex. The authors found that first-generation hybrids were viable but that both second-generation hybrids and back-crossed offsprings were of poor viability. Some showed morphological abnormalities, which suggested there were barriers to reproduction between A. brevispinus and COTSs. However, crossing experiments are very time- and resource-intensive, so indirect genetic methods are preferable. 


\section{The Usage of BINs for the Species of the Acanthaster planci Complex}

Since the seminal paper by Hebert et al. [34], partial mitochondrial COI gene sequences have been used as so called "DNA barcodes" with high success in nearly all metazoan taxa. Problems are mainly restricted to taxa with a net-like genealogy (hybrids, introgressions, etc.) and non-bilaterians, which frequently show highly conserved COI sequences $[35,36]$. However, available data strongly suggest that DNA barcoding is an excellent tool in discriminating echinoderm species [37-39]. As a general advantage, DNA barcode sequences do not change over an organism's lifetime, and can thus equally be applied to eggs, larva, adults, or the remains of animals.

Ratnasingham and Hebert [40,41] subsequently established the Barcoding of Life Data System (BOLD: [42]) as a global and open-access database for DNA barcodes. Already somewhat foreshadowed by certain authors (e.g., [43]), they [44] also introduced the Barcode Identification Number (BIN) system as a third step. A website with a distinct BIN number is provided for clusters of sequences, where sophisticated statistical analyses (see [45] for a comparative evaluation) have provided evidence for intraspecific continuity versus interspecific discontinuity (the so-called barcoding gap, [46]). Meanwhile, the BIN-framework is well established and has already become an international standard for re-identification of still unnamed or undetermined species (e.g., [47]). The BIN-site of the BOLD handbook [48] lists several points offered by the BIN-framework concerning all reliable data of specimens and species for the user, all these data and options are open access: (1) Details of BIN. (2) Taxonomy. (3) Tags \& Comments to be added. (4) Distance distribution. (5) Publications. (6) Tree reconstructions of BIN and nearest neighbor. (7) Haplotype network. (8) Collection location and data managers. For the BIN-numbers of the four currently recognized species of COTS, see Table 1.

Whereas there are as yet no clear diagnostic morphological characters available to clearly distinguish COTS species, species distinction based on DNA barcoding sequences are so far unequivocal and clear. Moreover, an openly accessible database with the Barcode Index Numbers for all currently recognized species of COTS is available, where sequences can be easily checked, compared, and added. Moreover, fast, cheap, and reliable routine protocols for mtDNA COI DNA barcode sequencing have been established to unequivocally determine the species identity of each COTS sample using the BIN framework [9-11].

\section{Recommendations}

In order to unequivocally allocate any kind of data on COTSs to the respective species, we make a number of recommendations:

(1) Provide and deposit a whole- or partial specimen voucher or tissue sample to your local public museum or collection with the exact sampling locality and inventory data, and request a voucher number. Add voucher number and metadata to any publication that arises. These vouchers, or at least parts thereof, should be suitable for molecular analyses, for example, stored in high percentage $(>95 \%)$ alcohol, but may be freeze-dried or frozen. The issue of voucher deposition is of particular importance for molecular studies $[49,50]$ and genome sequencing project such that future studies do not mismatch different species and one can go back to the actual specimens for (morphological) verification. Regrettably, no voucher specimens were kept from the two A. solaris specimens from which draft genomes were recently sequenced [42], so their morphology unfortunately cannot be examined.

(2) If possible, provide a COI barcode of your specimens, larvae or tissues, and use the BIN-code for unequivocal classification until the nomenclatorial prerequisites for valid Linnean binomens of all species are fulfilled (see [10] and above). Meanwhile, a good number of institutions (and the labs of Gerhard Haszprunar and Gert Wörheide) offer DNA barcoding services for a small fee, e.g., to cover consumables and sequencing. 
(3) Extend the knowledge about the biogeographic distribution of the at least four species of COTS. Of particular interest are potential areas of sympatry and areas that have not been covered so far (see [2,9-11]). Such areas include

a. areas of putative species sympatry/clade overlap (e.g., the southern coast of Oman, Yemen, and Somalia; Gulf of Aden; Western Indonesia);

b. $\quad$ sites close to the southern distribution limits of both Indian Ocean species;

c. $\quad$ sites close to the northern and southern distribution limits of $A$. solaris;

d. sites in the eastern Pacific to resolve the status of the putative species Acanthaster ellisii and Acanthaster ellisii pseudoplanci.

We here call for, and propose, an open biogeographic study within the framework of the recently established "Diversity of the Indo-Pacific Network" [51] to enhance our knowledge of the diversity of this coral predator. If collectors are unable to produce DNA barcode samples themselves, they are invited to send specimens or tissue samples suitable for molecular work to the lab of Gert Wörheide at LMU Munich.

Acknowledgments: Gert Wörheide acknowledges funding through "Institutional Strategy LMU excellent" by the Ludwig-Maximilians-Universität München within the framework of the German Excellence Initiative. We thank three anonymous reviewers and the editor for their valuable comments and recommendations.

Author Contributions: Gerhard Haszprunar and Gert Wörheide conceived the typescript, Catherine Vogler provided the photos and the basic parts of the text from a chapter of her Ph.D. thesis. Gerhard Haszprunar wrote the initial draft of the typescript, which was subsequently edited by Gert Wörheide and Catherine Vogler. All authors finally approved the typescript.

Conflicts of Interest: The authors declare no conflict of interest.

\section{References}

1. Pratchett, M.S.; Caballes, C.F.; Rivera-Posada, J.A.; Sweatman, P.A. Limits to understanding and managing outbreaks of crown-of-thorns starfish (Acanthaster spp.). Oceanogr. Mar. Biol. Ann. Rev. 2014, 52, 133-200.

2. Haszprunar, G.; Spies, M. An integrative approach of the crown-of-thorns starfish species group (Asteroidea: Acanthaster): A review of names and comparison to recent molecular data. Zootaxa 2014, 3841, 271-284. [CrossRef] [PubMed]

3. Fisher, W.K. Starfishes of the Philippine seas and adjacent waters. Bull. US Natl. Mus. 1919, 3, 100.

4. Nishida, M.; Lucas, J.S. Genetic differences between geographic populations of the crown-of-thorns starfish throughout the Pacific Ocean. Mar. Biol. 1990, 98, 359-368. [CrossRef]

5. Benzie, J.A.H. Major genetic differences between crown-of-thorns starfish (Acanthaster planci) populations in the Indian and Pacific Oceans. Evolution 1999, 53, 1782-1795. [CrossRef]

6. Benzie, J.A.H. The detection of spatial variation in widespread marine species: methods and bias in the analysis of population structure in the crown of thorns starfish (Echinodermata: Asteroidea). Hydrobiologia 2000, 420, 1-14. [CrossRef]

7. Gérard, K.; Roby, C.; Chevalier, N.; Thomassin, B.; Chenuil, A.; Féral, J.-P. Assessment of three mitochondrial loci variability for the crown-of-thorns starfish: A first insight into Acanthaster phylogeography. C. R. Biol. 2008, 331, 137-143. [CrossRef] [PubMed]

8. Yasuda, N.; Nagai, S.; Hamaguchi, M.; Okaji, K.; Gérard, K.; Nadaoka, K. Gene flow of Acanthaster planci (L.) in relation to ocean currents revealed by microsatellite analysis. Molec. Ecol. 2009, 18, 1574-1590. [CrossRef] [PubMed]

9. Vogler, C.; Benzie, J.; Lessios, H.; Barber, P.; Wörheide, G. A threat to coral reefs multiplied? Four species of crown-of-thorns starfish. Biol. Lett. 2008, 4, 696-699. [CrossRef] [PubMed]

10. Vogler, C.; Benzie, J.; Barber, P.H.; Erdmann, M.V.; Ambariyanto, S.C.; Tenggardjaja, K.; Gérard, K.; Wörheide, G. Phylogeography of the crown-of-thorns starfish in the Indian Ocean. PLoS ONE 2012, 7, e43499. [CrossRef] [PubMed] 
11. Vogler, C.; Benzie, J.A.H.; Tenggardjaja, K.; Ambariyanto, S.C.; Barber, P.H.; Wörheide, G. Phylogeography of the crown-of-thorns starfish: Genetic structure within the Pacific species. Coral Reefs 2013, 32, 515-525. [CrossRef]

12. Yasuda, N.; Hamaguchi, M.; Sasaki, M.; Nagai, S.; Saba, M.; Nadaoka, K. Complete mitochondrial genome sequences for crown-of-thorns starfish Acanthaster planci and Acanthaster brevispinus. BMC Genom. 2006, 7, 17. [CrossRef] [PubMed]

13. Timmers, M.A.; Bird, C.E.; Skillings, D.J.; Smouse, P.E.; Toonen, R.J. There's no place like home: Crown-of-thorns outbreaks in the central Pacific are regionally derived and independent events. PLoS ONE 2012, 7, e31159. [CrossRef] [PubMed]

14. Tusso, S.; Morcinek, K.; Vogler, C.; Schupp, P.J.; Caballes, C.F.; Vargas, S.; Wörheide, G. Genetic structure of the crown-of-thorns sea star in the Pacific. Peer J. 2016, 5, e1970. [CrossRef] [PubMed]

15. De Loriol, P. Catalogue raisonné des Echinodermes recuellis par M.V. de Robillard à l'Ile Maurice. II. Stellérides. Mem. Soc. Phys. Hist. Nat. Genéve 1885, 29, 1-84. (In French)

16. Schreber, J.C.D. von Beschreibung der Seesonne, einer Art Seesterne, mit 21 Strahlen. Der Naturforscher Halle a/d Saale 1793, 27, 1-6. (In German)

17. Ellis, J. The Natural History of Many Curious and Uncommon Zoophytes, Collected from Various Parts of The Globe; Benjamin White and Son: London, UK, 1786; pp. 1-12.

18. Nakajima, R.; Nakatomi, N.; Kurihara, H.; Fox, M.D.; Smith, J.E.; Okaji, K. Crown-of-Thorns starfish larvae can feed on organic matter released from corals. Diversity 2016, 8, 18. [CrossRef]

19. Nakamura, M.; Higa, Y.; Kumagai, N.H.; Okaji, K. Using long-term removal data to manage a Crown-of-Thorns Starfish population. Diversity 2016, 8, 24. [CrossRef]

20. Sigl, R.; Laforsch, C. The influence of water currents on movement patterns on sand in the Crown-of-Thorns Seastar (Acanthaster cf. solaris). Diversity 2016, 8, 25. [CrossRef]

21. Cowan, Z.-L.; Dworjanyn, S.A.; Caballes, C.F.; Pratchett, M. Benthic predators influence microhabitat preferences and settlement success of Crown-of-Thorns Starfish (Acanthaster cf. solaris). Diversity 2016, 8, 27. [CrossRef]

22. Buck, A.C.E.; Gardiner, N.M.; Bostrom-Einarsson, L. Citric acid injections: An accessible and efficient method for controlling outbreaks of the Crown-of-Thorns Starfish Acanthaster cf. solaris. Diversity 2016, 8, 28. [CrossRef]

23. Hall, M.R.; Kocot, K.M.; Baughman, K.W.; Fernandez-Valverde, S.L.; Gauthier, M.E.A.; Hatleberg, W.L.; Krishnan, A.; McDougall, C.; Motti, C.A.; Shoguchi, E.; et al. The crown-of-thorns starfish genome as a guide for biocontrol of this coral reef pest. Nature 2017, 544, 231-234. [CrossRef] [PubMed]

24. Bruckner, A.W.; Dempsey, A.C. The status, threats, and resilience of reef-building corals of the Saudi Arabian Red Sea. In The Red Sea. The Formation, Morphology, Oceanography and Environment of a Young Ocean Basin; Rasul, N.M.A., Steward, C.F., Eds.; Springer: Berlin/Heidelberg, Germany, 2015; pp. 470-486.

25. Madsen, F.J. A note on the seastar genus Acanthaster. Vidensk. Medd. Dansk Naturh. Foren. 1955, 117, $179-192$.

26. Caso, M.E. Estudios sobre Astéridos de México. Observaciones sobre especies pacíficas del género Acanthaster y descripción de una subespecie nueva, Acanthaster ellisii pseudoplanci. Anales Inst. Biol. Univ. Nacl. Autón. México 1962, 32, 313-331. (In Spanish)

27. Birkeland, C.; Lucas, J.S. Acanthaster Planci: Major Management Problem of Coral Reefs; CRC Press: Boca Raton, FL, USA, 1990; p. 267.

28. Campbell, A.; Ormond, R.F.G. The threat of the "crown-of-thorns" starfish (Acanthaster planci) to coral reefs in the Indo-Pacific area: Observations on a normal population in the Red Sea. Biol. Conserv. 1970, 2, $246-251$. [CrossRef]

29. Sweatman, H. No-take reserves protect coral reefs from predatory starfish. Curr. Biol. 2008, 18, R598-R599. [CrossRef] [PubMed]

30. Houk, P.; Raubani, J. Acanthaster planci outbreaks in Vanuatu coincide with ocean productivity, furthering trends throughout the Pacific Ocean. J. Oceanogr. 2011, 66, 435-438. [CrossRef]

31. Houk, P.; Bograd, S.; van Woesik, R. The transition zone chlorophyll front can trigger Acanthaster planci outbreaks in the Pacific Ocean: Historical confirmation. J. Oceanogr. 2007, 63, 149-154. [CrossRef]

32. Fabricius, K.E.; Okaji, K.; De'ath, G. Three lines of evidence to link outbreaks of the crown-of-thorns seastar Acanthaster planci to the release of larval food limitation. Coral Reefs 2010, 29, 593-605. [CrossRef] 
33. Lucas, J.S.; Jones, M.M. Hybrid crown-of-thorns starfish (Acanthaster planci X A. brevispinus) reared to maturity in the laboratory. Nature 1976, 263, 409-412. [CrossRef] [PubMed]

34. Hebert, P.D.N.; Cywinska, A.; Ball, S.L.; de Waard, J.R. Biological identifications through DNA barcodes. Proc. R. Soc. Lond. 2003, B270, 313-321. [CrossRef] [PubMed]

35. Shearer, T.L.; van Oppen, M.J.H.; Romano, S.L.; Wörheide, G. Slow mitochondrial DNA sequence evolution in the Anthozoa (Cnidaria). Molec. Ecol. 2002, 11, 2475-2487. [CrossRef]

36. Wörheide, G.; Erpenbeck, D. DNA taxonomy of sponges-Progress and perspectives. J. Mar. Biol. Ass. UK 2007, 87, 1629-1633. [CrossRef]

37. Ward, R.; Holmes, B.H.; O’Hara, T.D. DNA barcoding discriminates echinoderm species. Molec. Ecol. Res. 2008, 8, 1202-1211. [CrossRef] [PubMed]

38. Janosik, A.M.; Mahon, A.R.; Halanych, K.M. Evolutionary history of Southern Ocean Odontaster sea star species (Odontasteridae; Asteroidea). Polar Biol. 2011, 34, 575-586. [CrossRef]

39. Bucklin, A.; Steinke, D.; Blanco-Bercial, L. DNA barcoding of marine Metazoa. Ann. Rev. Mar. Sci. 2011, 3, 471-508. [CrossRef] [PubMed]

40. Ratnasingham, S.; Hebert, P.D.N. Bold: The barcode of life data system (www.barcodinglife.org). Molec. Ecol. Notes 2007, 7, 355-364. [CrossRef] [PubMed]

41. Ratsasingham, S.; Hebert, P.D.N. BOLD's role in barcode data management and analysis: A response. Molec. Ecol. Res. 2011, 11, 941-942. [CrossRef]

42. BOLD Systems. Available online: http://www.boldsystems.org/ (accessed on 10 May 2017).

43. Jones, M.; Ghoorah, A.; Blaxter, M. jMOTU and Taxonerator: Turning DNA barcode sequences into annotated operational taxonomic units. PLoS ONE 2011, 6, e19259. [CrossRef] [PubMed]

44. Ratsasingham, S.; Hebert, P.D.N. A DNA-based registry for all animal species: The Barcode Index Number (BIN) System. PLoS ONE 2013, 8, e66213.

45. Jörger, K.M.; Norenburg, J.L.; Wilson, N.G.; Schrödl, M. Barcoding against a paradox? Combined molecular species delineations reveal multiple cryptic lineages in elusive meiofaunal sea slugs. BMC Evol. Biol. 2012, 12, 245. [CrossRef] [PubMed]

46. Meyer, C.P.; Paulay, G. DNA barcoding: Error rates based on comprehensive sampling. Publ. Lib. Sci. Biol. 2005, 3, 2229-2238. [CrossRef] [PubMed]

47. Hausmann, A.; Godfray, H.C.J.; Huemer, P.; Mutanen, M.; Rougerie, R.; van Nieukerken, E.J.; Ratnasingham, S.; Hebert, P.D.N. Genetic patterns in European geometrid moths revealed by the Barcode Index Number (BIN) System. PLoS ONE 2013, 8, e84518. [CrossRef]

48. BOLD-Handbook-Barcode Index Numbers. Available online: www.boldsystems.org/index.php/ resources/handbook?chapter=2_databases.html\&section=bins (accessed on 10 May 2017).

49. Pleijel, F.; Jondelius, U.; Norlinder, E.; Nygren, A.; Oxelman, B.; Schander, C.; Sundberg, P.; Thollesson, M. Phylogenies without roots? A plea for the use of vouchers in molecular phylogenetic studies. Mol. Phylogenet. Evol. 2008, 48, 369-371. [CrossRef] [PubMed]

50. Astrin, J.J.; Zhou, X.; Misof, B. The importance of biobanking in molecular taxonomy, with proposed definitions for vouchers in a molecular context. ZooKeys 2013, 365, 67-70. [CrossRef] [PubMed]

51. Diversity of the Indopacific Network. Available online: http://diversityindopacific.net (accessed on 10 May 2017).

(C) 2017 by the authors. Licensee MDPI, Basel, Switzerland. This article is an open access article distributed under the terms and conditions of the Creative Commons Attribution (CC BY) license (http://creativecommons.org/licenses/by/4.0/). 